\title{
Penerapan Metode ADAM Pada Proses Investigasi Layanan Private Cloud Computing
}

\author{
Nur Widiyasono ${ }^{\# 1}$, Imam Riadi ${ }^{* 2}$, Ahmad Luthfi $^{\# 3}$ \\ \# Magster Teknik Informatika, Universitas Islam Indonesia \\ Jl. Kaliurang KM 14,5 Yogyakarta 55584 \\ ${ }^{1}$ nur.widiyasonodunsil.ac.id \\ 3ahmad.luthfi@uii.ac.id \\ * Teknologi Industri, Universitas Ahmad Dahlan \\ Jl. Prof. Dr. Soepomo, S.H. Janturan Yogyakarta 55164 \\ 2imam.riadieis.uad.ac.id
}

\begin{abstract}
Abstrak - Layanan Private Cloud Computing memiliki potensi terjadinya penyalahgunaan yang dilakukan oleh internal di dalam perusahaan, sebagai contoh kasus yang yang terjadi di RSIA XYZ. Penyalahgunaan tersebut terjadi dikarenakan adanya kelemahan sistem yang digunakan ,ataupun sebab lain. Proses akuisisi data pada layanan cloud computing penanganannya tidaklah sama dikarenakan jenis dan karakteristik layanan cloud computing tersebut. Isu mengenai masalah realibilitas data atau bagaimana proses data digital evidence didapatkan, pada persidangan akan menjadi perhatian khusus bagi majelis hakim, sehingga untuk menangani masalah tersebut digunakanlah metode ADAM (The Advance Data Acquisition Model), sayangnya metode tersebut belum pernah dilakukan evaluasi secara independen. Penelitian ini menggunakan metode $A D A M$ di dalam melakukan investigasi kasus pada layanan private cloud computing dan telah berhasil $100 \%$ menerapkannya, kemudian kontribusi pada penelitian ini telah menemukan penyebab potensi terjadinya penyalahgunaan layanan aplikasi owncloud tersebut.
\end{abstract}

Kata kunci-Akusisi, ADAM, Cloud, Forensik, Investigasi

\section{Pendahuluan}

Layanan cloud computing merupakan teknologi yang banyak ditawarkan oleh Cloud Service Provider (CSP) antara lain jenis yang ditawarkan adalah platform as a service (PaaS), infrastructure as a service (IaaS) dan software as a services (SaaS). Layanan tersebut memberikan berbagai kemudahan dan keuntungan bagi konsumen antara lain adalah self-service provisioning, Elasticity, dan pay per use. Layanan cloud terbagi menjadi 4 bagian yaitu private clouds, community cloud, public cloud dan hybrid cloud [1].

Private cloud dibangun untuk kebutuhan organisasi yang mencakup seluruh cloud infrastructure termasuk sumber daya hardware yang dimiliki organisasi tersebut. Community cloud adalah cloud yang digunakan secara bersama oleh organisasi yang memiliki jenis bisnis yang sama. Public Cloud adalah cloud yang dibangun dan digunakan oleh organisasi secara publik untuk kepentingan bisnisnya. Hybrid Cloud merupakan kombinasi dari private, community dan public cloud.

Layanan cloud yang ditawarkan diantaranya adalah hosted desktop yang merupakan mesin virtual pada cloud. Layanan ini memiliki aplikasi dan data-data yang berada pada remote data center. Pemilik layanan ini dapat melakukan akses aplikasi dan data melalui computer desktop. Layanan hosted desktop ini dapat disalahgunakan untuk melakukan kejahatan cyber [2]. Penyalahgunaan layanan ini dapat terjadi juga dikarenakan adanya kelemahan (bugs) dari sisi keamanan sistem tersebut. Menurut NIST, tahapan pada cloud computing forensics adalah identification, collection, preservation, examination, interpretation and reporting of digital evidence.

Penanganan kejahatan cyber tersebut diperlukan teknik akuisisi data, dimana teknik akusisi data dapat dilakukan secara live system ataupun write-block system [3]. Kedua teknik akuisisi data tersebut tidak hanya dilakukan pada layanan cloud computing, melainkan dapat dilakukan juga pada computer client, server, laptop atau notebook dan smartphone. Proses akusisi data secara live system maksudnya adalah proses untuk mendapatkan bukti digital dilakukan ketika sistem dalam keadaan hidup sedangkan write block system adalah proses akuisisi data yang dilakukan ketika sistem dalam keadaan mati misalnya proses akuisisi data pada harddisk.

Proses akuisisi data pada layanan cloud computing tidak dapat diperlakukan sama dikarenakan karakteristik layanan tersebut tidak sama [4]

Solusi yang diberikan pada masalah cloud forensics yaitu dengan memanfaatkan logging framework hal tersebut digunakan untuk memastikan bahwa data log yang berhasil dikumpulkan dapat digunakan untuk proses investigasi forensic [5]. Ada beberapa metode yang ditawarkan antara lain dengan metode ADAM (The Advance Data Acquisitions Model). Metode ini dikembangkan dalam kerangka untuk mengatasi masalah reabilitas data yaitu bagaimana data digital evidence didapatkan dan hal ini akan menjadi perhatian khusus di persidangan namun sayangnya metode $A D A M$ belum pernah dilakukan evaluasi secara independent [6].

\section{KAJIAN PUSTAKA}

Cloud Computing Forensic adalah aplikasi ilmu forensika digital yang berada lingkungan cloud computing, dan secara teknis yang dilakukan terdiri dari pendekatan forensic hybrid seperti remote, virtual, network, live, thin-client terhadap bukti digital dan secara organisasi melibatkan interaksi antara actor cloud computing untuk penyelidikan internal dan 
eksternal, serta secara hukum menyiratkan multi-yuridiksi dan situasi multi-penyewa [7].

Laporan dari National Institute of Standards and Technology mencatat bahwa panduan untuk memperoleh dan melakukan forensik pada layanan cloud computing dan menyarankan bahwa pedoman terbaik yang ada dan masih berlaku untuk melakukan forensik digital di lingkungan cloud computing[8]. Metode forensik digital yang ada, sudah tidak cocok untuk lingkungan cloud computing [9].

Pedoman dan panduan pada pengumpulan bukti digital sudah langka dan ketinggalan jaman. Tidak ada pedoman khusus untuk mengumpulkan bukti digital di Cloud Computing [10]. Penelitian yang ditemukan pada cloud computing ini sedikit, misalnya bagaimana untuk mengambil data dari layanan cloud secara forensik suara [11].

Pengamatan serupa digaungkan oleh sejumlah praktisi forensik digital, termasuk Direktur US Departemen Pertahanan Laboratorium Komputer Forensik dan Kepala Ilmuwan di US Air Force Research Laboratory Information Directorat yang mengemukakan bahwa " penelitian diperlukan dalam domain cyber, terutama dalam cloud computing, untuk melakukan identifikasi dan melakukan klasifikasi aspek unik di mana dan bagaimana bukti digital dapat ditemukan. Titik akhir seperti perangkat mobile juga berperan meningkatkan kompleksitas domain ini. Bukti jejak dapat ditemukan di server, switch, router, ponsel, dan lainlain[12].

Sudut pandang hukum, sistem cloud computing memiliki potensi tingkat kesulitan yang tinggi untuk melakukan proses analisis forensic computer seperti halnya untuk mendapatkan dan melakukan analisis bukti digital dengan standar yang sama seperti pada sistem server tradisional [13]. Hal tersebut disebabkan adanya kesulitan dalam membangun data-data yang disimpan atau diproses oleh software khusus. Penelitian pada tahap "collection" menjadi proses yang jauh lebih rumit di lingkungan cloud computing karena lokasi fisik data, distribusi data di beberapa server atau perangkat penyimpanan dan yurisdiksi, dan lain-lain[10][14].

Pembahasan pada framework NIST tentang identifikasi (identification) dan pelestarian (preservation) sebagai bagian dari fase koleksi (collection) sehingga hal ini menunjukkan bahwa fase identifikasi pada cloud computing lebih penting, sedangkan fase pelestarian harus bekerja sama dengan cloud service provider, kedua langkah tersebut penting di dalam penyelidikan pada cloud computing. Fase identifikasi dan fase pelestarian merupakan sumber bukti yang harus secara serentak dan secepat mungkin [17][15]. Contoh jika sumber data sudah teridentifikasi, maka harus segera menghubungi cloud service provider untuk memulai pelestarian.

Peran artefak (misalnya metadata) dalam analisis forensik dan (calon) hilangnya artefak ini ketika data dikumpulkan dari lingkungan cloud computing. Jika metadata (misalnya pembuatan / modifikasi tanggal file, dan log kepemilikan (pengguna) yang hilang selama proses pengumpulan, ini sangat berdampak kemampuan peneliti forensik untuk melakukan investigasi dengan standar yang dibutuhkan oleh pengadilan [16].
Proses forensika digital dapat dibagi menjadi empat fase yang berbeda :

- Koleksi artefak (baik bukti digital dan bahan pembantu) yang dianggap memiliki nilai potensial untuk dikumpulkan.

- Pelestarian artefak asli dengan cara yang handal, lengkap, akurat, dan dapat diverifikasi.

- Analisis penyaringan artefak untuk menghilangkan atau masuknya barang-barang yang dianggap berharga.

- Presentasi di mana bukti disajikan untuk mendukung penyelidikan

Secara tradisional, ada dua kategori forensika digital yaitu, static digital atau "write block" dan "live forensic", Zimmerman dan Glavach berpendapat bahwa ada dua kategori sebagai hasil dari evolusi forensic untuk menciptakan dan mendokumentasikan insiden secara canggih [17].

\section{METODOLOGI PENELITIAN}

Alur proses tahapan penelitian dapat digambarkan seperti Gambar 1 dibawah ini:

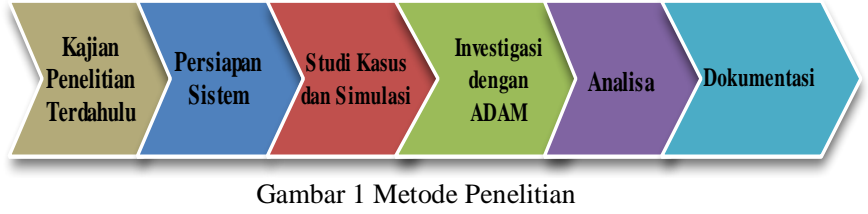

Kajian Penelitian terdahulu dilakukan untuk mengetahui masalah-masalah yang ada pada proses investigasi layanan cloud computing terutama yang terkait dengan proses akusisi data layanan cloud computing, metoda-metoda yang digunakan untuk melakukan proses akuisisi data, serta yang melatar belakangi isu dibalik metoda $A D A M$, sehingga dapat menunjang pada tujuan akhir dilakukannya penelitian ini.

Persiapan sistem merupakan tahapan dibangunnya layanan private cloud computing dengan menggunakan platform sistem operasi Microsoft Windows 2008 Advances server, VirtualMachine (VMware), OwnCloud-5.0.5 Server dengan memberikan ip public maka layanan private cloud ini dapat diakses melalui jaringan internet, maupun jaringan local dan hotspot. Layanan ini juga dapat diakses dengan menggunakan pc-desktop, notebook ataupun smartphone.

Studi kasus yang digunakan pada simulasi dilaboratorium jaringan komputer adalah kasus RSIA di kota Tasikmalaya yang namanya disamarkan menjadi RSIA XYZ. Kasus ini merupakan contoh terjadinya penyalahgunaan oleh seorang karyawan yang membocorkan rahasia perusahaan tersebut kepada pihak competitor. Private Digital Investigator memiliki tugas untuk mendapatkan bukti-bukti digital yang sangat potensial yang terdapat pada sisi layanan private cloud, $p c$ desktop ataupun smartphone yang digunakan tersangka. Diketahui setiap karyawan pada perusahaan RSIA XYZ dapat menggunakan fasilitas layanan private cloud ini sehingga dimungkinkan terjadi penyalahgunaan fasilitas tersebut untuk membocorkan rahasia perusahaan kepada kompetitornya.

Adapun topologi jaringan seperti pada gambar 2 dibawah ini: 


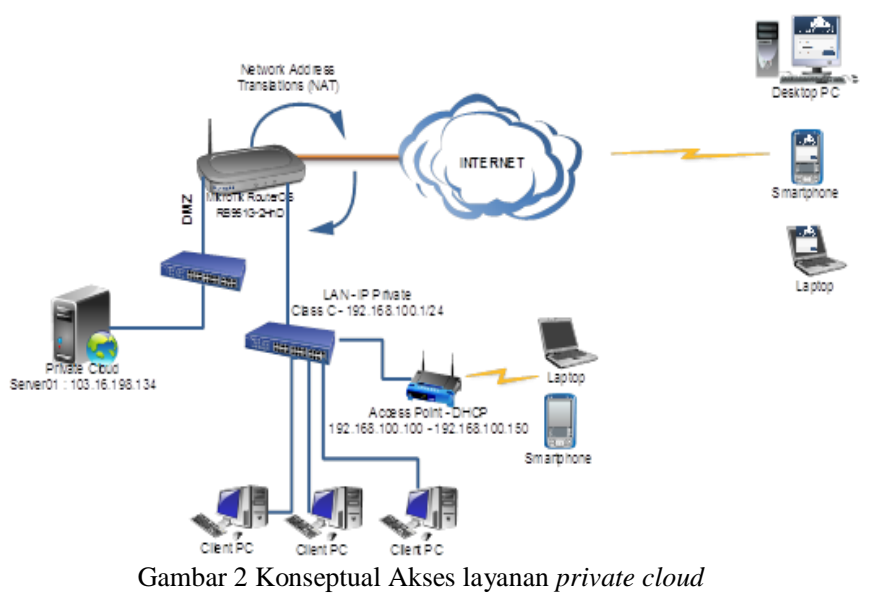

Investigasi terhadap simulasi kasus yang menggunakan layanan private cloud computing. Investigasi yang dilakukan diawali pada layanan private cloud computing atau dari sisi server, kemudian dari sisi network yaitu melakukan monitoring terhadap traffic data yang keluar atau masuk ke dalam server layanan private cloud computing dan mendapatkan digital evidence pada layer sessions (layer 5 pada 7 OSI layers) dengan menggunakan tool Wiresharks, kemudian melakukan investigasi terhadap desktop atau laptop serta smartphone yang terhubung ke layanan tersebut. Tolak ukur kesuksesan didalam melakukan investigasi adalah dapat diketahuinya lokasi atau posisi bukti digital baik yang berada di sisi private cloud server, pc desktop, laptop ataupun smartphone, disamping itu parameter lainnya adalah ip source, mac-address, username dan password, data log sistem, dapat membuka file enkripsi, sumberdaya (resources) lainnya yang dapat dijadikan bukti digital tambahan, kemudian bukti digital tersebut dapat dilakukan verifikasi dan kesesuaian antara bukti digital yang terdapat pada sisi private cloud server, pc desktop, laptop dan smartphone. Investigasi pada contoh kasus ini menggunakan metode ADAM (The Advance Data Acquisitions Model) yang memiliki 3 tahap yaitu:

(1) Perencanaan Awal (Initial Planning): Seorang senior investigator dan tim harus memahami tugas atau kasus akan dihadapi yaitu harus memiliki kemampuan detil tentang sistem computer / cloud system , jumlah dan lokasi data, jenis harddisk dan sistem operasi yang digunakan, disamping itu harus mampu menentukan gambaran secara menyeluruh tentang kasus yang dihadapi, menentukan hasil akhir yang diinginkan pada kasus yang dihadapi, menentukan parameter. Kemudian ada beberapa yang harus dipertimbangkan yakni adanya kendala-kendala seperti otorisasi secara internal, eksternal dan legal, kendala phisik terkait akses terhadap property yang lokasinya banyak, kendala waktu terkait perintah pengadilan terhadap property pribadi maupun komersial, kendala data yaitu jenis dan jumlah lokasi yang diidentifikasi, sehingga hal tersebut harus dibuat perencanaan dan persiapan serta logistic yang diperlukan. Simulasi kasus pada kajian penelitian ini, seorang senior investigator dan tim harus memahami kasus yang terjadi pada layanan private cloud computing dengan membuat perencanaan termasuk membentuk tim yang memiliki keahlian seperti yang telah disebutkan diatas. Beberapa lembar formulir yang telah disiapkan ditanda tangani oleh senior investigator dan selanjutnya dilakukan perencanaan yang akan dilakukan ditempat kejadian perkara.

(2) Perencanaan di Lokasi (The On Site Planning): Tahapan kedua dari proses metode $A D A M$, yaitu ketika berada dilokasi kejadian perkara maka senior investigator dan tim membuat rencana akuisisi utama, karena hal ini berkaitan dengan lokasi data, ukuran dan format data. Masalah keselamatan pada saat di tempat kejadian perkara, personil tim dan data-data akan memerlukan equipment yang dapat melakukan isolasi, disertai dengan melakukan update atau maintain terhadap dokumentasi atas seluruh aktifitas yang berlangsung (catatan kontemporer dari semua kegiatan), melakukan survey pendahuluan untuk memastikan lokasi data, menentukan identitas teknis, dan menentukan akuisisi campuran pada lokasi kejadian perkara atau dibawa ke laboratorium digital forensic. Kemudian melakukan update terhadap perencanaan yang akan digunakan pada tahapan proses metode ADAM selanjutnya.

(3) Akuisisi Data Digital (Acquisition Digital Data): Tahapan ketiga dari metode ADAM adalah akuisisi data digital yang dilakukan per perangkat dalam hal ini perangkat yang akan dilakukan akuisisi data pada sisi server layanan private cloud computing, dari sisi laptop/desktop maupun dari sisi smartphone atau perangkat yang digunakan oleh tersangka. Proses akuisisi data yang dilakukan oleh praktisi forensik digital harus mempertimbangkan beberapa hal, seperti data digital evidence sangatlah rapuh karena sifatnya yang mudah rusak (terkait dengan perangkat keras yang menyertainya), integritasnya sangatlah rentan terhadap perubahan (sangat mungkin dimodifikasi), bahkan kerusakan bisa saja terjadi karena kesalahan teknis atau human error. Penanganan yang sangat hati-hati perlu dilakukan, kesalahan dan kegagalan akan menyimpangkan hasil akhir bahkan menghilangkannya, sehingga dibutuhkan proteksi dan penanganan yang seksama akan otentisitas digital evidence.

Analisa merupakan tahapan untuk melakukan evaluasi terhadap proses investigasi kasus yang terjadi dengan memanfaatkan metode ADAM (The Advance Data Acquisition Model) atau Implementasi metode ADAM pada proses investigasi layanan private cloud computing dapat menghasilkan data digital evidence yang sesuai dan merupakan isu kritikal di dalam proses akusisi data sehingga dapat menjawab masalah realibilitas data atau proses untuk mendapatkan data digital evidence yang menjadi perhatian majelis hakim dipersidangan .

Dokumentasi merupakan tahapan dimana setiap tahapan dalam proses investigasi dilakukan pengarsipan atau dokumentasi, setiap perubahan ataupun didapatkannya data digital evidence pendukung dilakukan pencatatan / pembaruan dokumentasi. 


\section{HASIL DAN PEMBAHASAN}

Persiapan sistem yang dilakukan adalah dengan menguji masing-masing perangkat baik dari sisi client (smartphone, laptop ataupun $p c$ desktop) melalui internet ataupun local area network (LAN) dapat terhubung ke layanan private cloud sehingga hasil yang didapatkan seperti pada Tabel 1 dibawah ini :

TABEL I

HASIL VERIFIKASI CLIENT ACCESS MENUJU LAYANAN PRIVATE CLOUD COMPUTING

\begin{tabular}{|c|c|c|c|}
\hline No & Sumber & Status & Keterangan \\
\hline 1 & $\begin{array}{c}I P L A N \\
192.168 .2 .0 / 24 \\
192.168 .3 .0 / 24 \\
192.168 .4 .0 / 24 \\
192.168 .5 .0 / 24 \\
\text { HotSpot } \\
192.168 .100 .0 / 24\end{array}$ & $\begin{array}{l}\text { Terhubung } \\
\text { Terhubung } \\
\text { Terhubung } \\
\text { Terhubung } \\
\text { Terhubung }\end{array}$ & $\begin{array}{l}\text { Pc desktop, } \\
\text { Laptop } \\
\text { /notebook, } \\
\text { smartphone }\end{array}$ \\
\hline 2 & $\begin{array}{l}\text { Ip Publics Router } \\
\text { AT\&T }\end{array}$ & Terhubung & $\begin{array}{l}\text { International } \\
\text { Exchanges } \\
(I X)\end{array}$ \\
\hline 3 & $\begin{array}{l}\text { Ip Publics Router } \\
\text { iix.jk2.cyber }\end{array}$ & Terhubung & $\begin{array}{l}\text { Indonesian } \\
\text { Internet } \\
\text { Exchange } \\
(I I X)\end{array}$ \\
\hline 4 & $\begin{array}{l}\text { Smartphone - Lenovo } \\
780\end{array}$ & Terhubung & $\begin{array}{l}\text { Via HotSpot / } \\
\text { Access } \\
\text { Pointatau } \\
\text { Internet }\end{array}$ \\
\hline
\end{tabular}

Pemanfaatan aplikasi client oCloud.de ini dapat dilakukan melalui $p c$ desktop maupun smartphone, sedangkan pada smartphone koneksi ke layanan private cloud dapat dilakukan melalui akses internet maupun akses melalui access point / hotspot jaringan lokal.

Hasil proses investigasi yang dilakukan dengan metode $A D A M$ adalah sebagai berikut:

(1) Perencanaan Awal :

- Membuat perencanaan awal terkait kasus RSIA "XYZ Hospital" pembocoran Informasi rahasia perusahaan yang dilakukan oleh seorang karyawati kepada pihak lain, dimana Informasi tersebut didapatkan dengan memanfaatkan kelemahan dan kesalahan tata kelola layanan private cloud computing.

- Menentukan Tim yang akan terlibat di dalam proses investigasi kasus tersebut mencakup pemenuhan kompetensi IT yang diperlukan.

- Menentukan Software Aplikasi dan Tools yang diperlukan dalam investigasi tersebut.

- Membuat surat tugas/surat perintah yang diperlukan oleh petugas yang kemudian akan diteruskan kepada pihak Manajemen RSIA "XYZ Hospital”.

- Membuat dan melakukan pembaharuan terhadap setiap aktifitas yang dilakukan

(2) Perencanaan di lokasi:

- Menentukan sumber-sumber yang menjadi potensi data digital evidences seperti layanan private cloud server, layer 2 datalink, layer 3 network, layer 5 Session, dan layer 7 applications.

- Membuat rencana proses akusisi data dengan metode Live Acquisitions atau Write Block Acquisitions.

- Menentukan Aplikasi Software yang digunakan seperti WireSharks, Network Minner, WinISO atau UltraISO

(3) Akuisisi Data:

- Mendapatkan data digital evidences yang terdapat pada layanan private cloud system, pc desktop atau smartphone, dan perangkat network seperti switch dan router.

- Membuat laporan hasil investigasi

Tahapan Perencanaan Awal (Initial Planning) untuk menentukan tim digital forensic analyst investigator / terdiri dari ketua tim dan 2-3 anggota yang memiliki kompetensi keahlian dibidang IT secara umum , memiliki pengetahuan tentang teknologi virtualisasi / cloud computing, memahami berbagai sistem operasi seperti berbasis linux base, windows base, memahami struktur folder dan files, memahami tentang keamanan jaringan dan sistem seperti perangkat jaringan switch, router dan access-point, memahami tentang teknologi layanan berbasis mobile seperti smartphone. Selain itu tim investigator juga harus dapat menentukan jenis dan alat bantu yang akan digunakan untuk melakukan proses investigasi di lapangan seperti halnya menyiapkan perangkat lunak Wiresharks, Network Minner, UltraISO atau WinISO. Kemudian tim juga harus menyiapkan dokumen surat perintah atau surat tugas untuk melakukan proses investigasi penanganan kasus dan senantiasa melakukan update Informasi setiap aktifitas yang dilakukan.

Tahapan perencanaan di lokasi (the on site planning) tim investigasi menentukan sumber-sumber potensial data digital evidences yang terdapat pada layanan private cloud computing dan membuat rencana untuk menentukan proses akuisisi data secara live acquisitions atau write-block acquisitions. Proses akuisisi data yang dimaksud seperti pada gambar 4 dan gambar 5 kemudian setelah ditentukan proses yang akan dilakukan adalah menggunakan tools atau aplikasi piranti lunak yang dapat digunakan untuk melakukan proses akuisis data. Sejauh ini tidak ada consensus khusus mengenai software aplikasi yang digunakan untuk melakukan proses akuisisi data pada layanan cloud computing. Penelitian in menggunakan beberapa software aplikasi penunjang untuk melakukan proses akuisisi data baik secara live acquisitions ataupun write block acquisitions.

Gambar 4 merupakan alur proses untuk melakukan data live acquisitions dimana software aplikasi atau tools yang digunakan ditanam pada mesin layanan private cloud. Kemudian aktivasi sistem log yang berada pada layanan private cloud, router mikrotik dengan membuat rule (IPFirewall-Chain (Forward/Input/Output) - action log). Penangkapan data secara live acquisitions dilakukan pada layer 5 (session layer) dengan memanfaatkan perangkat lunak seperti wiresharks atau network minner. File yang dihasilkan dari proses penangkapan data pada layer 5 (session layer) adalah *.pcap (packet captures) atau*. Cscpkt (colasoft capsa 
packet) kemudian file tersebut dianalisa untuk ditemukan beberapa data bukti digital seperti jenis files, mac-address, username, password, log, dan time-stamp.

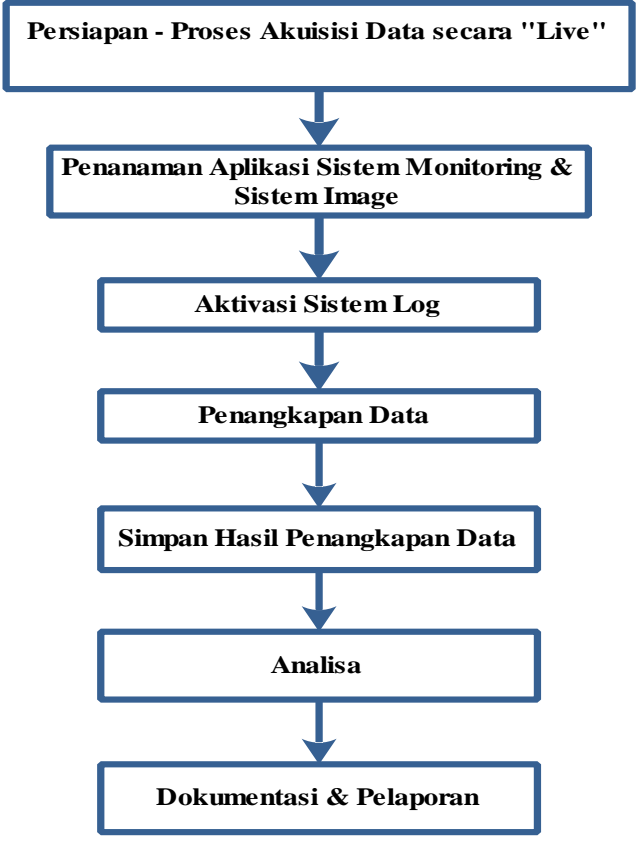

Gambar 4 Proses Data Live Acquisitions

Gambar 5 merupakan proses yang akusisi data secara writeblock, dimana seluruh akses yang mengarah ke layanan private cloud dilakukan blocking access sehingga data yang akan diakuisisi tidak mengalami perubahan atau dihilangkan oleh tersangka. Proses blocking access dapat dilakukan melalui perangkat mikrotik router os dengan membuat rules pada IP-Firewall-IP Destinations action drop.

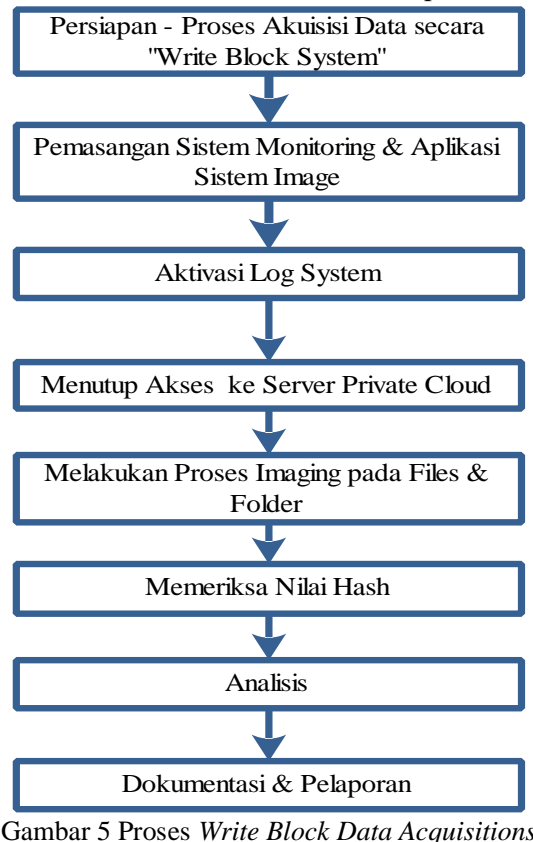

Sistem layanan private cloud ditanam aplikasi yang memiliki kemampuan untuk melakukan proses imaging file (*.iso atau *.dd) atau proses akusisi data dapat dilakukan secara remote ke mesin layanan private cloud meski melalui local area network (LAN). Simulasi kasus yang dilakukan menggunakan aplikasi UltraISO atau WinISO, setelah diketahui posisi folder dan files yang berada disisi mesin layanan private cloud computing kemudian dilakukan proses imaging files dan dilakukan pemeriksaan nilai hash pada files tersebut. Selanjutnya file image tersebut dilakukan analisa dan temukan files yang menjadi objek penyalahgunaan atau beberapa files yang dibocorkan kepada pihak ketiga pada simulasi kasus ini dan langkah selanjutnya adalah membuat laporan proses akuisisi data secara write-block. Proses akuisisi data dengan metode $A D A M$ dapat dilakukan per perangkat yang memiliki potensi sumber-sumber data digital evidences seperti server, pc desktop, smartphone, perangkat network seperti router mikrotik sehingga pada simulasi kasus dalam penelitian dapat disusun tabel data digital evidence yang ditemukan seperti pada tabel 2 sebagai berikut:

TABEL II

AKUISISI DATA PER DEVICE MENURUT METODE ADAM

\begin{tabular}{|l|l|c|c|c|c|}
\hline No & \multicolumn{1}{|c|}{ Parameter } & PCS & PC & Sp & $\boldsymbol{R}$ \\
\hline 1 & IP Source & $\sqrt{ }$ & $\sqrt{ }$ & $\sqrt{ }$ & $\sqrt{ }$ \\
\hline 2 & Mac Address Source & $\sqrt{ }$ & $\sqrt{ }$ & $\sqrt{ }$ & $\sqrt{ }$ \\
\hline 3 & IP Destinations & $\sqrt{ }$ & - & - & $\sqrt{ }$ \\
\hline 4 & $\begin{array}{l}\text { Mac Address } \\
\text { Destination }\end{array}$ & $\sqrt{ }$ & - & - & $\sqrt{ }$ \\
\hline 5 & $\begin{array}{l}\text { Struktur Folder dan } \\
\text { Files }\end{array}$ & $\sqrt{ }$ & $\sqrt{ }$ & $\sqrt{ }$ & - \\
\hline 6 & Log Activity - System & $\sqrt{ }$ & $\sqrt{ }$ & - & $\sqrt{ }$ \\
\hline 7 & $\begin{array}{l}\text { Username dan } \\
\text { Password }\end{array}$ & $\sqrt{ }$ & $\sqrt{ }$ & $\sqrt{ }$ & - \\
\hline 8 & Time Stamp & $\sqrt{ }$ & $\sqrt{ }$ & $\sqrt{ }$ & $\sqrt{ }$ \\
\hline 9 & Data Locations & $\sqrt{ }$ & $\sqrt{ }$ & $\sqrt{ }$ & - \\
\hline 10 & Protocol \& Port Access & $\sqrt{ }$ & $\sqrt{ }$ & $\sqrt{ }$ & $\sqrt{ }$ \\
\hline 11 & Browser-artefact & $\sqrt{ }$ & $\sqrt{ }$ & $\sqrt{ }$ & - \\
\hline
\end{tabular}

Keterangan: PCS: Private Cloud Server, PC: Personal Computer Sp: Smartphone, R: Router

Tabel 2 diatas untuk mendapatkan mac-address asli dari sumbernya sulit untuk diketahui disebabkan ketika perangkat $p c$ desktop ataupun smartphone ketika terhubung ke perangkat network seperti router maka mac-address yang digunakan adalah mac-address pada perangkat router.

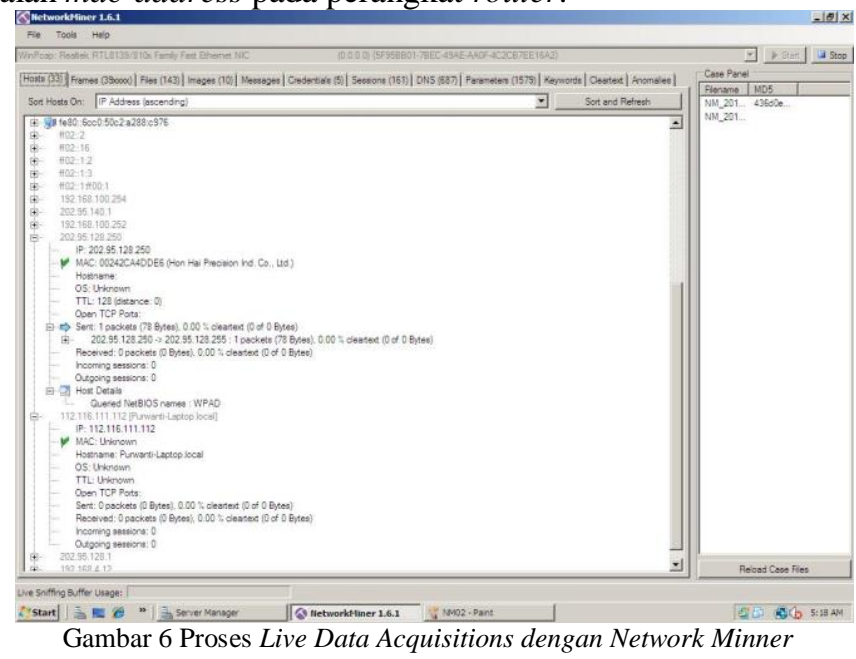

Gambar 6 merupakan hasil penangkapan data trafik menuju ke mesin private cloud dengan menggunakan Network Minner 
di dapatkan bahwa client access dengan ip public (202.95.128.xxx) yang melewati perangkat router akan menggunakan mac-address router (D4CA6D688907) tersebut demikian halnya dengan perangkat ( $p c$ desktop/smartphone) yang melalui access-point / hotspot ketika melakukan akses ke layanan private cloud dan melalui perangkat router maka akan didapati menggunakan mac-address router.

Menggunakan network minner akan didapatkan host, frames, files, image, message, credentials, sessions, DNS(s), parameters, keyword, cleartext, anomalies, hasil penangkapan data akan disimpan pada file berekstensikan .pcap (packet captures).Memanfaatkan fitur-fitur yang dimiliki oleh network minner dapat memberikan hasil yang diperlukan di dalam proses akuisisi data secara live.

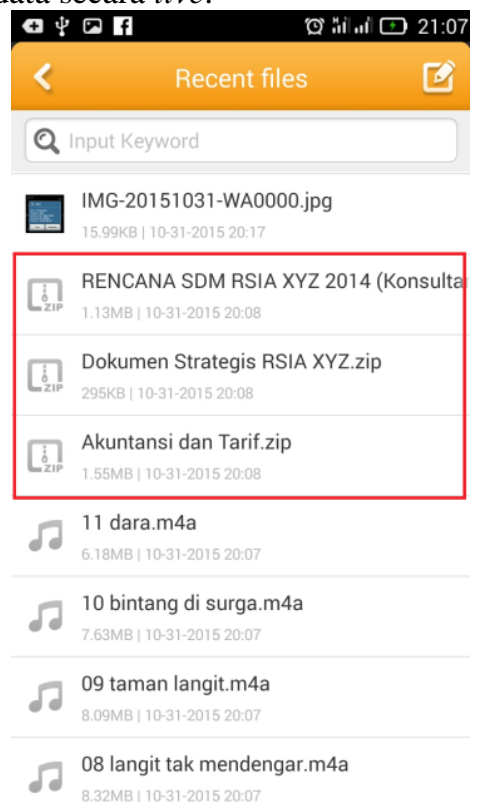

Gambar 7 Data Digital Evidence pada Smartphone

Gambar 7 diatas merupakan hasil investigasi pada perangkat smartphone, investigator dapat menemukan 3 files yang di duga berkaitan dengan kasus pada RSIA XYZ.

Merujuk pada hasil investigasi dengan menggunakan metode $A D A M$, maka di dapatkan hasil bahwa penyebab terjadinya penyalahgunaan layanan private cloud pada RSIA XYZ adalah manajemen user pada aplikasi OwnCloud versi 5.0.5 server memiliki kelemahan sehingga antara user satu dengan lainnya dalam kelompok group yang sama dapat merubah password. Verifikasi temuan data digital evidence pada komputer desktop, perangkat smartphone dan sisi server private cloud computing, maupun proses akusisi data secara live ataupun write-block acquisition dapat dilakukan sehingga capaian keberhasilan metode $A D A M$ dalam proses investigasi layanan private cloud computing adalah $100 \%$. Keberhasilan investigasi dalam kasus RSIA XYZ adalah dapat ditemukannya lokasi files folder data digital evidences, username dan password, time stamps, ip address dan macaddress, dan kesesuaian file-file data digital evidence yang didapatkan pada perangkat smartphone, komputer desktop dan pada komputer private cloud computing.
Peningkatan keamanan untuk meminimalisir terjadinya penyalahgunaan dapat memanfaatkan teknologi layanan virtual private network, menggunakan produk yang memiliki fasilitas manajemen user lebih baik, dan kebijakan manajemen perusahaan di dalam menggunakan layanan private cloud computing agar lebih diperketat dan dibatasi pada pengguna tertentu saja

\section{KESIMPULAN DAN SARAN}

Penggunaan metode ADAM (The Advance Data Acquisition Model) pada proses investigasi layanan private cloud computing telah berhasil dilakukan dan proses akuisisi data pada layanan tersebut dapat dilakukan baik secara live ataupun write-block acquisition per perangkat sehingga masalah realibilitas data digital evidence tersebut dapat dipertanggungjawabkan di persidangan. Merujuk kasus yang terjadi pada RSIA XYZ potensi penyalahgunaan terhadap tersebarnya informasi data yang bersifat rahasia dapat terjadi disebabkan oleh kelemahan sistem yang digunakan, ataupun telah terjadi kesalahan konfigurasi dan tidak digunakannya kebijakan access policy terhadap layanan private cloud computing.

Penelitian yang dapat dilakukan selanjutnya adalah melakukan analisa atau asessment terhadap piranti lunak atau piranti keras yang digunakan untuk melakukan proses akuisisi data pada layanan cloud computing, karena sampai dengan saat ini masih belum ada konsensus mengenai standarisasi penggunaannya.

\section{REFERENSI}

[1] Emma Webb Hobson. (2010). "Digital Investigations in the Cloud." Farnborough, UK:QinetiQ Digital Investigations Service

[2] Hogan Lovell, Winston Maxwell, Christopher Wolf, (2012) DCA Global Reality: Governmental Access to Data in the Cloud A comparative analysis of ten international jurisdictions, Hogan Lovell White papers.13.

[3] Marthie Lessing, Basie von Solms (2011), "Live Forensic Acquisition as Alternative to Traditional Forensic Processes", Council for Scientific and Industrial Research Meiring Naudé Road, Scientia Pretoria, South Africa, 2011.

[4] Bodenheimer, D. Z. (2012), Cloud Computing Acquisitions \& Cyber security. Briefing Papers, No. 12-11, 20.

[5] Raffael Marty (2011), "Cloud application logging for forensics," in proceedings of the 2011 ACM Symposium on Applied Computing. ACM, 2011, pp. 178-184, 2011.

[6] Richard Adams, V. H. (2013), The Advanced Data Acquisition Model (ADAM): A Process Model For Digital Forensic Practice. Journal of Digital Forensics, Security and Law, Vol. 8(4), 24.

[7] Keyun Ruan, P. J. (2011). Cloud forensics: An overview. IBM Ireland $L t d, 16$.

[8] National Institute of Standard and Technology (NIST) 2011,Challenging security requirements for US government Cloud Computing adoption, U.S. Department of Commerce, National Institute of Standards and Technology, Gaitherbug

[9] Barrett, D \& Kipper, G (2010), Virtualization and Forensics: a digital forensic investigator's guide to virtual environments, Syngress.

[10] Birk, D \& Wegener, C (2011), Technical Issues of forensics IInvestigations in cloud computing environments, Sixth International Workshop on Systematic Approaches to Digital Forensic Engineering (SADFE), IEEE.

[11] Huber M, Mulazzani M, Leithner M, Schrittwieser S, Wondracek G,Weippl, E, (2011). Social snapshots: digital forensics for online social networks, In: Annual Computer Security Applications 
Conference - ACSAC 2011, Orlando, Florida, USA; 2011, pp. 113122.

[12] Zatyko, K \& Bay, J .(2011), The Digital forensics cyber exchange principle, Forensics Magazine, pp.5-13.

[13] Taylor M, Haggerty J, Gresty D, Lamb D, (2011). Forensic investigation of cloud computing systems. Network Security, (3):4-10.

[14] McKemmish R, (1999). What is forensic computing? Trends \& Issues in Crime and Criminal Justice;118:1-6

[15] Kent, K., Chevalier, S., Grance, T., \& Dang, H.(2006). Guide to Integrating Forensic Techniques into Incident Response. In National
Institute of Standards and Technology (Ed.) (Vol. 800-86): U.S Department of Commerce.

[16] Reilly, D, Wren, C \& Berry, T (2010), Cloud Computing: Forensics Challenges for Low enforcement, International Conference for Internet Technology and Secured Transactions (ICITST), IEEE.

[17] S. Zimmerman and D. Glavach (2011), "Cyber Forensics in the Cloud," IA Newsletter, vol. 14, no. 1, pp. 4-7; http://iac.dtic.mil/iatac/download/Vol14_No1.pdf. 